\title{
Job Satisfaction among Government and Private School Teachers of Ranchi
}

\author{
Dr. Smritikana Mitra Ghosh ${ }^{1}$
}

\section{ABSTRACT:}

In present study the researcher investigated the level of job satisfaction among the private and government school teachers. Total 200 government and private school teachers were taken from Ranchi town. In this research, 100 government and 100 private school teachers, 200 in total, working in different government and private schools were examined. Job satisfaction scale developed by Muthayya (1973) was used to measured job satisfaction. To test the hypotheses ' $t$ ' test was calculated. Result showed that there was no significant difference between government and private school teachers. Furthermore, it was again revealed that there was no significant difference in the level of job satisfaction of male and female school teachers.

Keywords: Job Satisfaction, Government, Private and School Teachers

\section{INTRODUCTION:}

Job satisfaction is the contribution of two words - 'job' and 'satisfaction'. Job is an occupational activity performed by an individual in return for is ward. Job satisfaction portrays the perception of the person towards his or her job, job related activities and environment. It is a combination of psychological and emotional experiences at work. Satisfaction refers to inner containment or happiness for the person engaged in any job. It shows the relationship between 'what one expects' and 'what one achieves', No task can effectively be accomplished unless a person derives enough of satisfaction out of it because the work plays an important role in the life of a man.

One of the most important purposes to do a job is to earn money because it is money only through which needs, demands can be fulfilled. If one gets a handsome salary by which one can afford the living may cause job satisfaction. But if the salary cannot bear ones expenditure then one cannot be satisfied with the salary. Findings from several studies underline pay as one of the most important factors influencing one's level of job satisfaction. Sometimes it has also been found that other job related factors are not satisfactory but pay is good, in these kind of situations employees are willing to serve the organizations just because of good pay, which does not suit the profession of a teacher.

\footnotetext{
${ }^{1} \mathrm{Ph} . \mathrm{D}$, Ranchi University, Ranchi, Jharkhand \& India
} 
Thus job satisfaction may be a resultant feeling of satisfaction which the employee achieves by gaining from the job what he expects from it to satisfy his needs. It may be a function of the need straight or expectation and the potentiality of the job to provide for the fulfillment of needs.

Job satisfaction is the attitude of an employee which results from specific factors related with job such as wages, supervision, steadiness of employment, conditions of work, opportunities for advancement, recognition of ability, fair evaluation of the job, prompt with grievances, fair treatment by employer and other similar items. Job satisfaction is positive attitude towards one's job. A large number of research studies have established that job satisfaction is derived from caused by a number of inter related factors. A concept related to job satisfaction is job involvement. Job satisfaction of employees has been reported to vary with their occupational levels. Jab satisfaction means good or positive attitude or feeling towards one's job. It is important to mention that an individual may told different attitudes toward various aspects of the job. Character of individuals also influences job satisfaction. Individuals with high positive effectively are more likely to be satisfied with their jobs. Job satisfaction is determined by how well the result of the job meets the expectations of the employee or they exceed the expectations. Some important factors influencing job satisfaction may be classified in two categories-

A) Environmental factors:-Job content, Occupational level, Pay and promotion and Supervision.

B) Personal factors:-Age, Sex, Educational level, Marital status and Experience.

\section{REVIEW OF LITERATURE}

Job satisfaction is one of the most researched concepts. It is regarded as central to work and organizational psychology. It serves as a mediator for creating relationship between working conditions, on the one hand, and individual / organizational outcome on the other (Dorman \& Zapf, 2001). Chen (2010) found that there exists no significant difference in the mean scores of government school teachers with respect to gender and there exists significant differences in private school teachers with respect to gender. John (2010), Mehta (2012) and Zilli and Zahoor (2012) studied on job satisfaction among teachers to know whether the perception of job satisfaction among teachers was affected by the types of organization and gender. Kumari and Jafri (2011) mentioned a study on level of organizational commitment of male and female teachers of secondary school to investigate the overall level of organizational commitment of male and female teachers of secondary school of Aligarh Muslim University. Data analyzed by using t-test result revealed that overall percentage of female teacher's organizational commitment was much higher than male teachers. Suki and Suki (2011) examined on job satisfaction and organizational commitment: the effect of gender on employee perception of job satisfaction and organizational commitment. Study revealed that employee's gender has no significant effect on his/her perception of job satisfaction and men and women have the same level of organizational commitment. Zilli and Zahoor (2012) conducted a study to find out the organizational commitment among male and female higher education teachers and to compare the organizational commitment among male and female higher education teachers. Result 
revealed that the females had significantly higher level of organization commitment. Kumar and Bhatia (2011) mentioned that the level of job satisfaction and attitude of the teachers towards teaching is least affected by the gender, the marital status, minimum qualification and income group of physical education teachers to compare the job satisfaction among physical education teachers and their attitude towards teaching.

Mehta (2012) investigated on job satisfaction among teachers to know whether the perception of job satisfaction among teachers was affected by the type of organization and the gender. Descriptive analysis was made to study the perception of job satisfaction of male vs. female and t-test was used. Result showed that there would be significant difference in the level of job satisfaction of government and private school teachers. Joshi (1998) found that employees of public sector as well as private sector have shown considerable job satisfaction. The mean difference between the employees of public and private sector on job satisfaction at 0.01 level $(\mathrm{t}=6.47)$ while the employees of public sector have exhibited more job satisfaction, the employees of private sector have exhibited relatively less job satisfaction.

\section{OBJECTIVES}

1. To study the job satisfaction of government and private school teachers.

2. To study the job satisfaction of teachers with respect to gender.

\section{HYPOTHESES}

1. There will be no significant difference between government and private school teacher.

2. There will be no significant difference between male and female school teacher.

\section{METHOD}

\section{Sample}

The sample of the study consisted of the teachers working in government and private schools of Ranchi town. A sample of 200 teachers consisting 100 private school teachers (50 were male and 50 female) and 100 government school teachers(50 were male and 50 female) were taken into consideration.

\section{Instrument}

Job Satisfaction Scale -The job satisfaction scale has been developed by Muthayya (1973). The scale consists of 34 items measuring job satisfaction. Each item is presented with four response alternatives namely agree, disagree, not sure, not applicable. Scoring is done on the basis of a key given in the manual. The score range is $0-68$. The higher score indicates the lesser job satisfaction. The split half technique of reliability (odd - even items) was used for the 34 items job satisfaction scale is .81 after applying the Spearman-Brown prophecy formula.

\section{Procedure}

The job satisfaction scale administered to both groups with instructions. Scoring was done according to the respective scoring keys. In order to fulfill the objective of the study the score obtained were analysed with mean, SD's and t values. 


\section{RESULTS AND INTERPRETATION}

The data were analysed by Means, SDs and t test. Tables present the result.

Table -1

Comparison of government and private school teacher on job satisfaction

\begin{tabular}{|c|c|c|c|c|c|}
\hline Groups & N & Mean & SDs & t & P value \\
\hline Government school teacher & 100 & 32.59 & 4.28 & \multirow{2}{*}{1.06} & $\begin{array}{c}\text { Not } \\
\text { Significant }\end{array}$ \\
\hline Private school teacher & 100 & 31.97 & 4.09 & \\
\hline
\end{tabular}

Figure - 1

Mean scores of government and private school teacher on job satisfaction

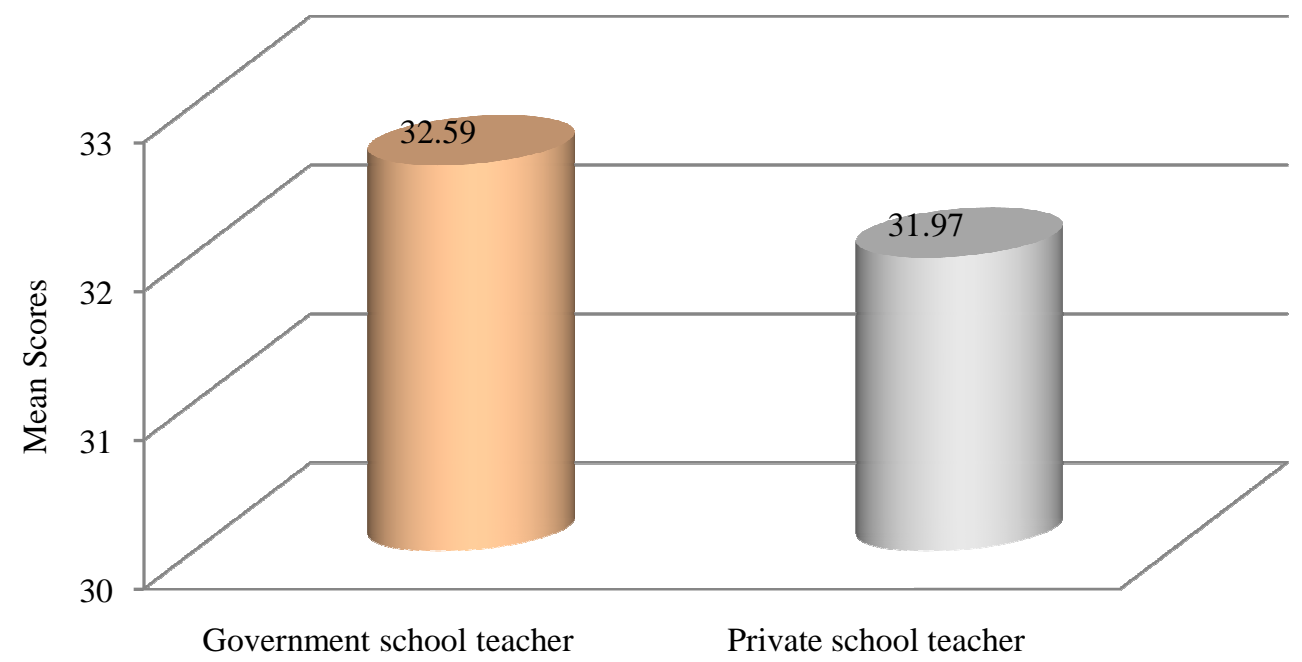

From the table -1 and figure -2 it was evident that teachers of government and private school showed almost similar level of job satisfaction. Calculated ' $t$ ' value was 1.06 which was statistically not significant even 0.05 level of significance. Hence, the hypothesis there will be no significant difference between government and private school teacher was accepted. 
Table - 2

Comparison of male and female school teacher on job satisfaction

\begin{tabular}{|c|c|c|c|c|c|}
\hline Groups & N & Mean & SDs & t & P value \\
\hline Male school teacher & 100 & 34.54 & 6.01 & \multirow{2}{*}{0.92} & $\begin{array}{c}\text { Not } \\
\text { Significant }\end{array}$ \\
\hline
\end{tabular}

Figure - 2

Mean scores of male and female school teacher on job satisfaction

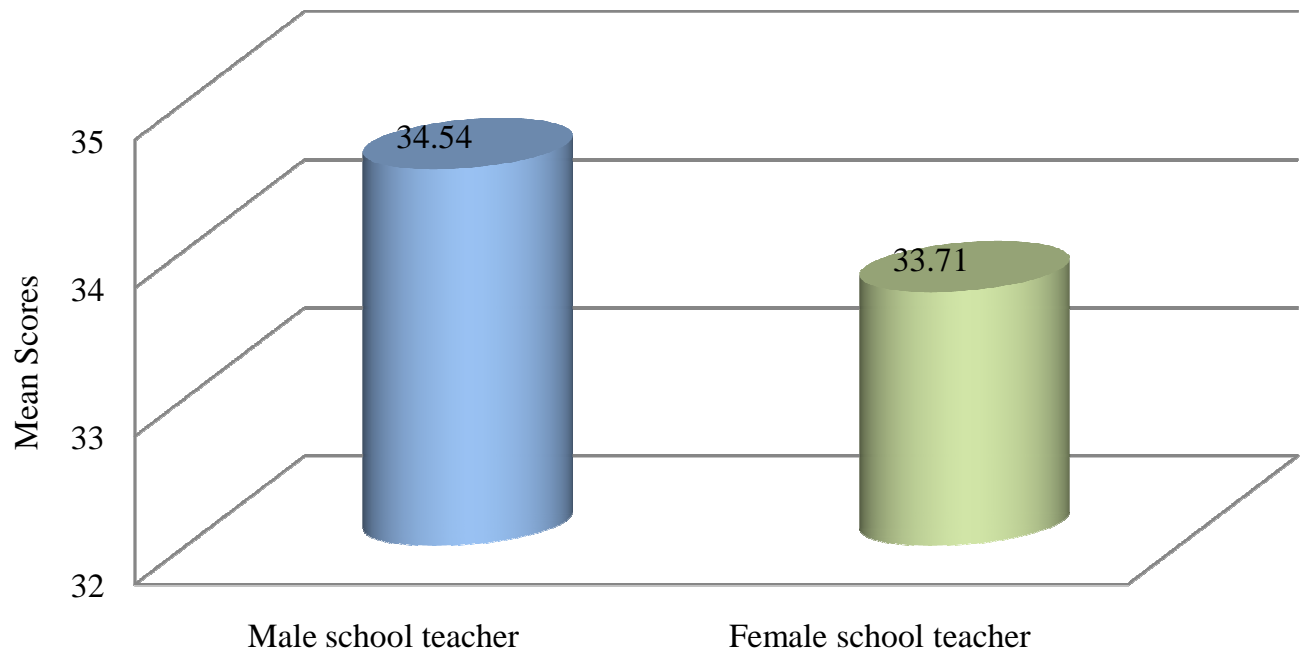

The Table -2 and figure -2 suggests that there was no significant difference between male and female school teachers on their job satisfaction. The mean score of male school teacher was slightly higher than female school teachers, it means female school teachers had slightly higher satisfaction with their job than male school teachers. But, their difference was not significant. Thus, the hypothesis there will be no significant difference between male and female school teacher was accepted.

\section{CONCLUSIONS}

1. Government and private school teachers had similar level of job satisfaction.

2. Male and female school teachers also found similar level of job satisfaction. 


\section{REFERENCES}

1. Chen, J. (2010). Chinese middle school teacher job satisfaction and its relationships with teacher moving. Asia Pacific Education Review, 11(3), 263-272.

2. Dorman, B \& Zapf, C. (2001). Job satisfaction among hospital doctors in Norway and Germany. A comparative study on national sample health journal. 37(3); 503-508.

3. John, J. (2010). Motivation and job satisfaction of catholic school teachers. Online Submission, Paper presented at the annual meeting of the American educational research association.

4. Joshi, G. (1998). Job satisfaction, job involvement and work involvement among the employees of private and public sectors. Psychological Studies. 43, (3); 85-90.

5. Kumar, K \& Bhatia, L. (2011). Teachers and their attitude towards teaching; Asia Pacif. Journal of Research in Business Management. Vol-2.Issue 9, 67-77.

6. Mehta, D. S. (2012). Job satisfaction among teachers. International Journal of Research in Commerce IT \& Management, 2(4), 77-83.

7. Suki, N \& Suki, N. (2011). Job Satisfaction and Organizational Commitment: The Effect of Gender. International Journal of Psychology Research, 6(5), 1-15.

8. Zilli, A. S \& Zahoor, Z. (2012). Organizational Commitment among Male and Female Higher Education Teachers. Indian Journal of Psychology and Education, 2(1), 55-60. 